\title{
A low-temperature solution-processed copper antimony iodide rudorffite for solar cells
}

\author{
Xue Jia ${ }^{1,2}$ and Liming Ding ${ }^{1,2^{*}}$
}

\begin{abstract}
A copper antimony iodide rudorffite, $\mathrm{Cu}_{3} \mathrm{SbI}_{6}$, was first prepared by using a low-temperature solution-processing approach. Its film absorbs 320-520 $\mathbf{~ m m}$ light and has an indirect bandgap of $2.43 \mathrm{eV}$. Solar cells with a structure of ITO/PEDOT:PSS/ $\mathrm{Cu}_{3} \mathrm{SbI}_{6} / \mathrm{PC}_{61} \mathrm{BM} / \mathrm{Al}$ were made, giving a power conversion efficiency of $0.50 \%$ and a fill factor of $67.09 \%$.
\end{abstract}

Keywords: copper antimony iodide rudorffite, low-temperature solution-processing, solar cells

\section{INTRODUCTION}

Perovskite solar cells (PSCs) using organic lead halide perovskites as light-absorbing materials have experienced a tremendous development in recent years, as perovskite materials have outstanding optoelectronic properties and can be solution-processed. In 2009, Miyasaka et al. [1] incorporated $\mathrm{CH}_{3} \mathrm{NH}_{3} \mathrm{PbI}_{3}$ as sensitizers into dye-sensitized solar cells (DSSCs), achieving a power conversion efficiency (PCE) of 3.8\%. Then great efforts have been made to crystallization methods, interface engineering, device architectures and large-area device fabrication [26]. Within just a few years, the PCE for perovskite solar cells has been boosted to $22.7 \%$ [7], showing great promise in commercialization. Despite the fast development of PSCs [8-10], the device stability and lead toxicity of organic lead halide perovskites are still great challenges, which will perplex the commercialization of PSCs. Thus scientists have made great effort in designing new leadfree perovskite materials and analogues recently $[11,12]$.

Tin and germanium are ideal candidates for substitution of lead as they are elements of 14 group in the periodic table, and $\mathrm{Sn}^{2+}$ and $\mathrm{Ge}^{2+}$ have similar electronic configuration as $\mathrm{Pb}^{2+}$ [11]. Thus Sn-based and Ge-based halide perovskites have been studied recently $[13,14]$.
However, both $\mathrm{Sn}^{2+}$ and $\mathrm{Ge}^{2+}$ can be easily oxidized into $\mathrm{Sn}^{4+}$ and $\mathrm{Ge}^{4+}$, respectively, which harms the photovoltaic performance.

Antimony, an element of group 15, is another promising alternative to lead, as trivalent $\mathrm{Sb}^{3+}$ has similar electronic configuration and comparable electronegativity as $\mathrm{Pb}^{2+}$. Antimony halide perovskites with the basic formula $\mathrm{A}_{3} \mathrm{Sb}_{2} \mathrm{X}_{9}\left(\mathrm{~A}=\mathrm{CH}_{3} \mathrm{NH}_{3}{ }^{+}, \mathrm{Cs}^{+}, \mathrm{Rb}^{+}, \mathrm{NH}_{4}^{+} ; \mathrm{X}=\mathrm{Cl}^{-}, \mathrm{Br}^{-}\right.$, $\mathrm{I}^{-}$), with $0 \mathrm{D}$ dimer or $2 \mathrm{D}$ layered structure, have been investigated recently [15,16]. Kirchartz et al. [17] used $\left(\mathrm{CH}_{3} \mathrm{NH}_{3}\right)_{3} \mathrm{Sb}_{2} \mathrm{I}_{9}$ as the absorber of solar cells, achieving a PCE of $0.49 \%$. Moreover, $\mathrm{Cs}_{3} \mathrm{Sb}_{2} \mathrm{I}_{9}$ and $\mathrm{Rb}_{3} \mathrm{Sb}_{2} \mathrm{I}_{9}$ have been studied theoretically and experimentally, and their optoelectronic properties were investigated $[18,19]$. Recently, our group reported a family of lead-free perovskite materials $\left(\mathrm{NH}_{4}\right)_{3} \mathrm{Sb}_{2} \mathrm{I}_{x} \mathrm{Br}_{9-x}(0 \leq x \leq 9)$ [20].

More recently, silver bismuth halide rudorffites were reported [21]. $\mathrm{AgBi}_{2} \mathrm{I}_{7}$ with a $1.8 \mathrm{eV}$ bandgap, a $3 \mathrm{D}$ silver iodobismuthate in a cubic $F d \overline{3} m$ structure $(a=b=c=$ $12.223 \AA$ ), was reported by Sargent group, giving a PCE of $1.22 \%$ when it was used as the light absorber of solar cells [22]. $\mathrm{Ag}_{2} \mathrm{BiI}_{5}$, a hexagonal crystal with space group $R \overline{3} \mathrm{~m}$, presents a direct bandgap $\left(E_{\mathrm{g}}\right)$ of $1.85 \mathrm{eV}$ and gives a PCE over $2 \%$ [23]. $\mathrm{Ag}_{3} \mathrm{BiI}_{6}\left(E_{\mathrm{g}}=1.85 \mathrm{eV}\right)$ with $3 \mathrm{D} R \overline{3} m$ rudorffite structure was also reported. Solar cells with a structure of $\mathrm{FTO} / \mathrm{c}-\mathrm{TiO}_{2} / \mathrm{m}-\mathrm{TiO}_{2} / \mathrm{Ag}_{3} \mathrm{BiI}_{6} / \mathrm{PTAA} / \mathrm{Au}$ were made, giving a PCE of $\sim 4 \%$ [24]. Silver bismuth halide rudorffites are alternative materials for lead halide perovskite solar cells because of their good optoelectronic properties and good stability under ambient conditions. However, copper antimony halide rudorffites and their photovoltaic performance have not been reported before.

In this work, copper antimony halide rudorffite thin films were prepared by spin-coating followed by annealing at low temperature. Light absorption, XRD pattern

${ }^{1}$ Center for Excellence in Nanoscience (CAS), Key Laboratory of Nanosystem and Hierarchical Fabrication (CAS), National Center for Nanoscience and Technology, Beijing 100190, China

${ }^{2}$ University of Chinese Academy of Sciences, Beijing 100049, China

* Corresponding author (email: Ding@nanoctr.cn) 
and morphology of the rudorffite films were studied. Solar cells with a structure of indium tin oxide (ITO)/poly(3,4ethylenedioxythiophene):polystyrene sulfonate (PEDOT: $\mathrm{PSS}) / \mathrm{Cu}_{3} \mathrm{SbI}_{6} /[6,6]$-phenyl- $\mathrm{C}_{61}$-butyric acid methyl ester $\left(\mathrm{PC}_{61} \mathrm{BM}\right) / \mathrm{Al}$ were made, giving a $\mathrm{PCE}$ of $0.50 \%$ and an FF of $67.09 \%$.

\section{EXPERIMENTAL SECTION}

\section{Preparation of rudorffite precursor}

The mixed powder of $\mathrm{CuI}$ and $\mathrm{SbI}_{3}$ (molar ratio 3:1) was dissolved in dimethyl sulfoxide (DMSO) with a concentration of $35 \mathrm{wt} \%$. The solution was stirred at $70^{\circ} \mathrm{C}$ for $2 \mathrm{~h}$, and then cooled to room temperature. All rudorffite precursor solutions were filtered by using a $0.45 \mu \mathrm{m}$ polytetrafluoroethylene (PTFE) filter before being spincoated.

\section{Characterization}

Absorption spectra of the rudorffite films on glass substrates were recorded on a Shimadzu UV-1800 spectrophotometer. X-ray diffraction (XRD) patterns were obtained on D/MAX-TTRIII (CBO) with $\mathrm{Cu}$ Ka radiation $(\lambda=1.542 \AA)$ operating at $40 \mathrm{kV}$ and $200 \mathrm{~mA}$. Film thicknesses were measured with a profilometer (KLA Tencor D-120). Atomic force microscopy (AFM) was performed on a Multimode microscope (Veeco) (tapping mode). Scanning electron microscopy (SEM) was performed on a Hitachi SU8220.

\section{Device fabrication and measurements}

Patterned ITO substrates with a sheet resistance of $15 \Omega \mathrm{sq}^{-1}$ was ultrasonically cleaned by using detergent, deionized water, acetone and isopropanol sequentially and then treated with UV-ozone for $10 \mathrm{~min} .30 \mathrm{~nm}$ thick PEDOT:PSS (Clevios ${ }^{\mathrm{TM}} \mathrm{P}$ VP Al 4083) films were formed by spin-coating an aqueous dispersion onto ITO substrates $(4,000 \mathrm{rpm}$ for $30 \mathrm{~s})$. PEDOT:PSS substrates were dried at $150^{\circ} \mathrm{C}$ for $10 \mathrm{~min}$. Then rudorffite precursor solutions were spin-coated onto PEDOT:PSS films at $4,000 \mathrm{rpm}$ for $60 \mathrm{~s}$, followed by annealing at $70^{\circ} \mathrm{C}$ for 2 min. $\mathrm{PC}_{61} \mathrm{BM}$ solution ( $15 \mathrm{mg} \mathrm{mL}^{-1}$ in chlorobenzene) was then spin-coated onto rudorffite films at 2,000 rpm for $30 \mathrm{~s}$. Finally aluminum $(100 \mathrm{~nm})$ was deposited onto $\mathrm{PC}_{61} \mathrm{BM}$ layer through a shadow mask under vacuum (ca. $10^{-4} \mathrm{~Pa}$ ). The effective area for the devices is $4 \mathrm{~mm}^{2}$. The current density-voltage $(J-V)$ curves were measured by using a computerized Keithley 2400 SourceMeter and a Xenon-lamp-based solar simulator (Enli Tech, AM 1.5G, $100 \mathrm{~mW} \mathrm{~cm}^{-2}$ ). The illumination intensity of solar si-
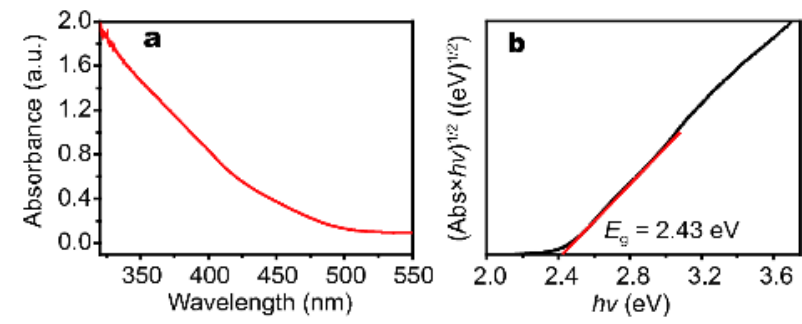

Figure 1 UV-vis absorption spectrum (a) and Tauc plot (b) of $\mathrm{Cu}_{3} \mathrm{SbI}_{6}$ film.

mulator was determined by using a monocrystalline silicon solar cell (Enli SRC2020, $2 \mathrm{~cm} \times 2 \mathrm{~cm}$ ) calibrated by NIM (National Institute of Metrology, China). The external quantum efficiency (EQE) spectra were measured by using a QE-R3011 measurement system (Enli Tech).

\section{RESULTS AND DISCUSSION}

Cuprous iodide (CuI) has low solubility in organic solvents, such as dimethyl formamide (DMF) and DMSO, which are common solvents for lead-based perovskites. However, the mixture of $\mathrm{CuI}$ and antimony iodide $\left(\mathrm{SbI}_{3}\right)$ can easily dissolve in DMSO at $70^{\circ} \mathrm{C}$, since $\left[\mathrm{SbI}_{3+x}\right]^{]^{-}}$ions might form [24]. In this work, copper antimony iodide rudorffite precursor solution was prepared by dissolving the mixture of $\mathrm{CuI}$ and $\mathrm{SbI}_{3}$ (molar ratio 3:1) in DMSO. $\mathrm{Cu}_{3} \mathrm{SbI}_{6}$ films were obtained by spin-coating the precursor solution onto the substrates, then annealed at $70^{\circ} \mathrm{C}$ for 2 min. $\mathrm{Cu}_{3} \mathrm{SbI}_{6}$ films present yellow color.

$\mathrm{Cu}_{3} \mathrm{SbI}_{6}$ film absorbs light at $320-520 \mathrm{~nm}$ and an absorption onset locates at $\sim 510 \mathrm{~nm}$ (Fig. 1a). If $\mathrm{Cu}_{3} \mathrm{SbI}_{6}$ is regarded as an indirect bandgap semiconductor, the Tauc plot is shown in Fig. $1 \mathrm{~b}$, and $E_{\mathrm{g}}$ could be $2.43 \mathrm{eV}$. The direct bandgap is estimated to be $2.77 \mathrm{eV}$ (Fig. S1).

The X-ray diffraction (XRD) pattern of $\mathrm{CuI}$ powder presents diffraction peaks at $25.5^{\circ}, 29.5^{\circ}, 42.2^{\circ}, 50.0^{\circ}$ and $52.3^{\circ}$ (Fig. 2). The pattern of $\mathrm{SbI}_{3}$ powder presents diffraction peaks at $12.7^{\circ}, 25.5^{\circ}, 27.0^{\circ}, 35.1^{\circ}, 41.8^{\circ}, 45.9^{\circ}$ and $52.4^{\circ}$. The pattern of $\mathrm{Cu}_{3} \mathrm{SbI}_{6}$ powder is quite different from that of $\mathrm{CuI}$ and $\mathrm{SbI}_{3}$. Some new diffraction peaks, e.g., $15.0^{\circ}, 20.2^{\circ}, 23.4^{\circ}, 26.0^{\circ}, 29.3^{\circ}, 31.0^{\circ}, 40.3^{\circ}$ and $49.1^{\circ}$, show up, implying that new compounds may form. The single crystal of $\mathrm{Cu}_{3} \mathrm{SbI}_{6}$ cannot be obtained, and we are not clear about the exact structure of the new compound.

The surface morphologies for $\mathrm{Cu}_{3} \mathrm{SbI}_{6}$ films were studied by SEM and AFM. Though $\mathrm{Cu}_{3} \mathrm{SbI}_{6}$ films prepared without annealing and with annealing at low temperature look uniform (Fig. S2), their nanoscale morphologies in SEM images are quite different. The film without annealing exhibits flocculus-like structure (Fig. 3a). After being an- 


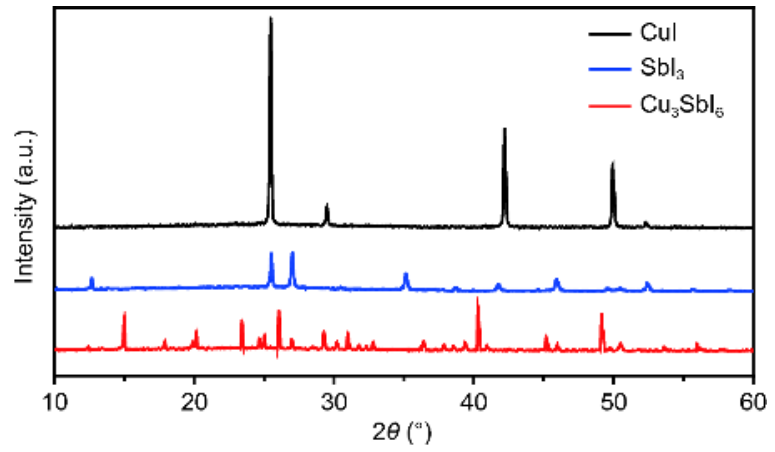

Figure $2 \mathrm{XRD}$ patterns for $\mathrm{CuI}, \mathrm{SbI}_{3}$ and $\mathrm{Cu}_{3} \mathrm{SbI}_{6}$ powders.

nealed at $70^{\circ} \mathrm{C}$, the film presents evenly-distributed nanograins with diameters around $50 \mathrm{~nm}$ (Fig. 3b). As annealing temperature increases to $100^{\circ} \mathrm{C}$, many agglomerates and voids formed in the films, which might result from $\mathrm{Cu}_{3} \mathrm{SbI}_{6}$ decomposition (Fig. $3 \mathrm{c}$ and Fig. S3c). The morphology change was also observed in AFM images (Fig. S4). The film annealed at $70^{\circ} \mathrm{C}$ looks quite uniform with evenly-distributed nano-structures, and its rootmean-square (RMS) roughness is $0.17 \mathrm{~nm}$. The films prepared without and with annealing at $100^{\circ} \mathrm{C}$ are rougher, having RMS roughness of 0.25 and $1.51 \mathrm{~nm}$, respectively.
Solar cells with a structure of ITO/PEDOT:PSS/ $\mathrm{Cu}_{3} \mathrm{SbI}_{6} / \mathrm{PC}_{61} \mathrm{BM} / \mathrm{Al}$ were made to investigate the photovoltaic properties of $\mathrm{Cu}_{3} \mathrm{SbI}_{6}$ (Fig. 4a). The $J-V$ characteristic of $\mathrm{Cu}_{3} \mathrm{SbI}_{6}$ solar cells is shown in Fig. 4b. An open-circuit voltage $\left(V_{\mathrm{OC}}\right)$ of $0.704 \mathrm{~V}$, a short-circuit current density $\left(J_{\mathrm{SC}}\right)$ of $1.05 \mathrm{~mA} \mathrm{~cm}^{-2}$, a fill factor $(\mathrm{FF})$ of $67.09 \%$ and a PCE of $0.50 \%$ were obtained. The annealing temperature and time for $\mathrm{Cu}_{3} \mathrm{SbI}_{6}$ film were optimized (Tables S1, S2). The best annealing temperature is $70^{\circ} \mathrm{C}$. The thickness of $\mathrm{Cu}_{3} \mathrm{SbI}_{6}$ film was optimized (Table S3) and $135 \mathrm{~nm} \mathrm{Cu} \mathrm{SbI}_{6}$ film gave the best performance. Thicker active layer could absorb more light, producing more photocurrent. PCE decreases when the thickness of $\mathrm{Cu}_{3} \mathrm{SbI}_{6}$ film is further increasing, which results from charge recombination and higher resistance. The EQE spectrum shows a maximum of $21.55 \%$, and it yields an integrated current density of $0.9 \mathrm{~mA} \mathrm{~cm}^{-2}$ (Fig. 4c). The stability for $\mathrm{Cu}_{3} \mathrm{SbI}_{6}$ solar cells was studied when stored in a $\mathrm{N}_{2}$ glovebox $\left(\mathrm{O}_{2}<10 \mathrm{ppm} ; \mathrm{H}_{2} \mathrm{O}<0.1 \mathrm{ppm}\right)$. The PCE remained $>87 \%$ of the initial value after 40 days, indicating good device stability (Fig. S5).

To understand the charge recombination in the material, the variation of $J_{\mathrm{SC}}$ with light intensity $(I)$ was studied (Fig. S6). The relationship between $J_{\mathrm{SC}}$ and $I$ can be described by the formula $J_{\mathrm{SC}} \propto I^{\alpha}$ [25]. If all free charge carriers are swept out and collected at electrodes prior to
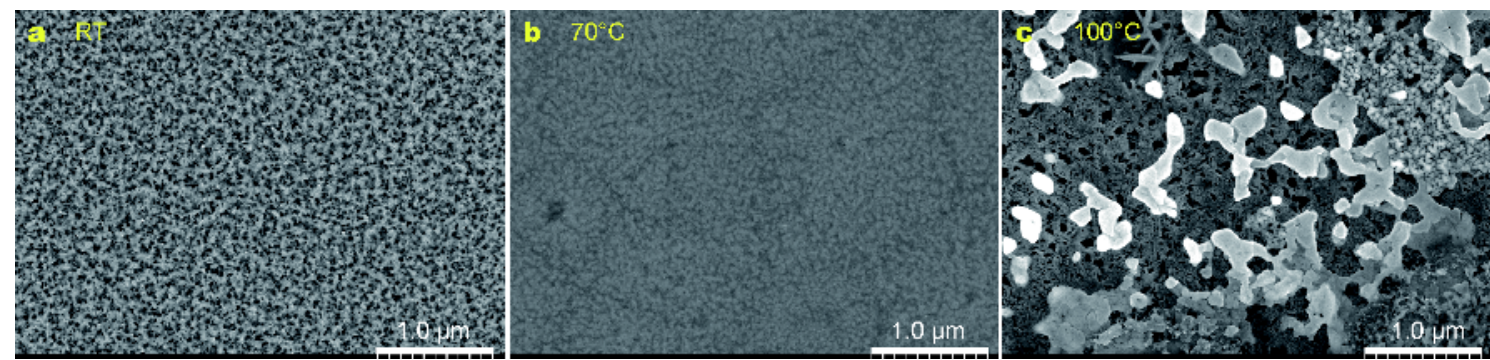

Figure $3 \mathrm{SEM}$ images for $\mathrm{Cu}_{3} \mathrm{SbI}_{6}$ films on glass substrates with annealing at $\mathrm{RT}(\mathrm{a}), 70^{\circ} \mathrm{C}$ (b) and $100^{\circ} \mathrm{C}(\mathrm{c})$.
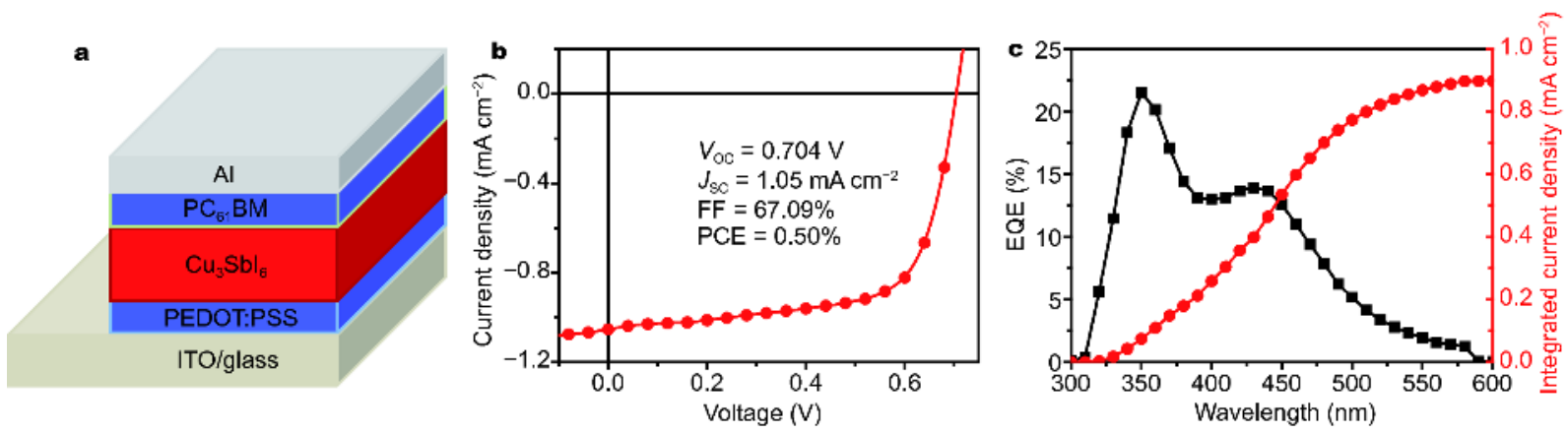

Figure 4 The structure (a), $J-V$ curve (b) and EQE spectrum (c) of the $\mathrm{Cu}_{3} \mathrm{SbI}_{6}$ solar cell. 
recombination, $\alpha=1$. $\alpha$ for $\mathrm{Cu}_{3} \mathrm{SbI}_{6}$ solar cell is 0.958 , indicating bimolecular recombination. The variation of $V_{\mathrm{OC}}$ with natural logarithm of light intensity was also studied (Fig. S7). The slope is $1.34 k T / q$, where $k$ is Boltzmann constant, $T$ is the temperature in Kelvin and $q$ is the elementary charge, suggesting that less monomolecular recombination was involved [26].

\section{CONCLUSIONS}

In summary, copper antimony iodide rudorffite $\mathrm{Cu}_{3} \mathrm{SbI}_{6}$ was developed and its films were prepared via spincoating followed by annealing at low temperature. $\mathrm{Cu}_{3}$ $\mathrm{SbI}_{6}$ film absorbs $320-520 \mathrm{~nm}$ light. The annealing condition and the device performance were optimized. A PCE of $0.50 \%$ and an FF of $67.09 \%$ were obtained from the $\mathrm{Cu}_{3} \mathrm{SbI}_{6}$ solar cells.

Received 27 March 2018; accepted 14 May 2018;

published online 8 June 2018

1 Kojima A, Teshima K, Shirai Y, et al. Organometal halide perovskites as visible-light sensitizers for photovoltaic cells. J Am Chem Soc, 2009, 131: 6050-6051

2 Zuo C, Ding L. An 80.11\% FF record achieved for perovskite solar cells by using the $\mathrm{NH}_{4} \mathrm{Cl}$ additive. Nanoscale, 2014, 6: 9935-9938

3 Fakharuddin A, Schmidt-Mende L, Garcia-Belmonte G, et al. Interfaces in perovskite solar cells. Adv Energy Mater, 2017, 7: 1700623

4 Zuo C, Ding L. Modified PEDOT layer makes a $1.52 \mathrm{~V} V_{\text {oc }}$ for perovskite/PCBM solar cells. Adv Energy Mater, 2017, 7: 1601193

5 Eperon GE, Hörantner MT, Snaith HJ. Metal halide perovskite tandem and multiple-junction photovoltaics. Nat Rev Chem, 2017, 1: 0095

6 Zuo C, Vak D, Angmo D, et al. One-step roll-to-roll air processed high efficiency perovskite solar cells. Nano Energy, 2018, 46: 185192

7 https://www.nrel.gov/pv/assets/images/efficiency-chart.png, 2017.10.30

8 Zuo C, Bolink HJ, Han H, et al. Advances in perovskite solar cells. Adv Sci, 2016, 3: 1500324

9 Jeon T, Kim SJ, Yoon J, et al. Hybrid perovskites: effective crystal growth for optoelectronic applications. Adv Energy Mater, 2017, 7: 1602596

10 Chen B, Zheng X, Bai Y, et al. Progress in tandem solar cells based on hybrid organic-inorganic perovskites. Adv Energy Mater, 2017, 7: 1602400

11 Lyu M, Yun JH, Chen P, et al. Addressing toxicity of lead: progress and applications of low-toxic metal halide perovskites and their derivatives. Adv Energy Mater, 2017, 7: 1602512

12 Shi Z, Guo J, Chen Y, et al. Lead-free organic-inorganic hybrid perovskites for photovoltaic applications: recent advances and perspectives. Adv Mater, 2017, 29: 1605005

13 Krishnamoorthy T, Ding H, Yan C, et al. Lead-free germanium iodide perovskite materials for photovoltaic applications. J Mater Chem A, 2015, 3: 23829-23832

14 Zhao Z, Gu F, Li Y, et al. Mixed-organic-cation tin iodide for leadfree perovskite solar cells with an efficiency of $8.12 \%$. Adv Sci, 2017, 4: 1700204

15 Boopathi KM, Karuppuswamy P, Singh A, et al. Solution-processable antimony-based light-absorbing materials beyond lead halide perovskites. J Mater Chem A, 2017, 5: 20843-20850

16 Jiang F, Yang D, Jiang Y, et al. Chlorine-incorporation-induced formation of the layered phase for antimony-based lead-free perovskite solar cells. J Am Chem Soc, 2018, 140: 1019-1027

17 Hebig JC, Kühn I, Flohre J, et al. Optoelectronic properties of $\left(\mathrm{CH}_{3} \mathrm{NH}_{3}\right)_{3} \mathrm{Sb}_{2} \mathrm{I}_{9}$ thin films for photovoltaic applications. ACS Energy Lett, 2016, 1: 309-314

18 Saparov B, Hong F, Sun JP, et al. Thin-film preparation and characterization of $\mathrm{Cs}_{3} \mathrm{Sb}_{2} \mathrm{I}_{9}$ : A lead-free layered perovskite semiconductor. Chem Mater, 2015, 27: 5622-5632

19 Harikesh PC, Mulmudi HK, Ghosh B, et al. Rb as an alternative cation for templating inorganic lead-free perovskites for solution processed photovoltaics. Chem Mater, 2016, 28: 7496-7504

20 Zuo C, Ding L. Lead-free perovskite materials $\left(\mathrm{NH}_{4}\right)_{3} \mathrm{Sb}_{2} \mathrm{I}_{x} \mathrm{Br}_{9-x}$. Angew Chem Int Ed, 2017, 56: 6528-6532

21 Baranwal AK, Masutani $\mathrm{H}$, Sugita $\mathrm{H}$, et al. Lead-free perovskite solar cells using $\mathrm{Sb}$ and Bi-based $\mathrm{A}_{3} \mathrm{~B}_{2} \mathrm{X}_{9}$ and $\mathrm{A}_{3} \mathrm{BX}_{6}$ crystals with normal and inverse cell structures. Nano Convergence, 2017, 4: 26

22 Kim Y, Yang Z, Jain A, et al. Pure cubic-phase hybrid iodobismuthates $\mathrm{AgBi}_{2} \mathrm{I}_{7}$ for thin-film photovoltaics. Angew Chem Int Ed, 2016, 55: 9586-9590

23 Zhu H, Pan M, Johansson MB, et al. High photon-to-current conversion in solar cells based on light-absorbing silver bismuth iodide. ChemSusChem, 2017, 10: 2592-2596

24 Turkevych I, Kazaoui S, Ito E, et al. Photovoltaic rudorffites: leadfree silver bismuth halides alternative to hybrid lead halide perovskites. ChemSusChem, 2017, 10: 3754-3759

25 Koster LJA, Mihailetchi VD, Xie H, et al. Origin of the light intensity dependence of the short-circuit current of polymer/fullerene solar cells. Appl Phys Lett, 2005, 87: 203502

26 Kumar MH, Dharani S, Leong WL, et al. Lead-free halide perovskite solar cells with high photocurrents realized through vacancy modulation. Adv Mater, 2014, 26: 7122-7127

Acknowledgements We greatly appreciate the National Natural Science Foundation of China (U1401244, 51773045, 21572041, 21772030, 51503050 and 21704021) and the National Key Research and Development Program of China (2017YFA0206600) for financial support.

Author contributions Jia X did the experiments, analysed the data and prepared the manuscript. Ding L directed this project and revised the manuscript.

Conflict of interest The authors declare that they have no conflict of interest.

Supplementary information Supporting data are available in the online version of the paper. 


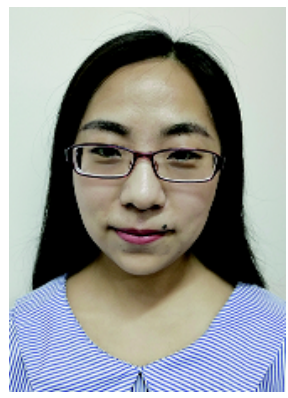

Xue Jia got her BSc degree from Hubei University in 2015. She is now a PhD student in the University of Chinese Academy of Sciences under the supervision of Prof. Liming Ding. Her research focuses on perovskite solar cells and organic solar cells.



Liming Ding got his PhD from the University of Science and Technology of China. He started his research on OSCs and PLEDs in Olle Inganäs Lab in 1998. Later on, he worked with Frank Karasz and Tom Russell at PSE, UMASS Amherst. He joined Konarka as a Senior Scientist in 2008. In 2010, he joined the National Center for Nanoscience and Technology as a Full Professor. Currently, his work focuses on perovskite solar cells and BHJ solar cells.

\section{一种低温溶液法制备的铜锑碘化合物及其太阳电池应用}

贾雪 ${ }^{1,2}$, 丁黎明 ${ }^{1,2^{*}}$

摘要 本文运用低温溶液法首次制备了一种铜锑碘化合物 $\mathrm{Cu}_{3} \mathrm{SbI}_{6}$, 其薄膜可以吸收长为 $320-520 \mathrm{~nm}$ 的光, 具有 $2.43 \mathrm{eV}$ 的间接带隙. 以其 作为吸光层制备了结构为ITO/PEDOT:PSS $/ \mathrm{Cu}_{3} \mathrm{SbI}_{6} / \mathrm{PC}_{61} \mathrm{BM} / \mathrm{Al}$ 的太阳电池, 能量转换效率为 $0.50 \%$, 填充因子为 $67.09 \%$. 